\title{
Non-linkage of the islet amyloid polypeptide gene with Type 2 (non-insulin-dependent) diabetes mellitus
}

\author{
J.T.E.Cook ${ }^{1}$, P.P.Patel ${ }^{1}$, A.Clark ${ }^{1}$, J.W.M.Höppener ${ }^{3}$, C.J.M.Lips ${ }^{4}$, S.Mosselman ${ }^{3}$, S.O'Rahilly ${ }^{1}$, R.C.Page ${ }^{1}$, \\ J.S. Wainscoat ${ }^{2}$ and R.C. Turner ${ }^{1}$ \\ 1 Diabetes Research Laboratories, Radcliffe Infirmary, \\ 2 Department of Heamatology, John Radcliffe Hospital, Oxford, UK, \\ ${ }^{3}$ Institute of Molecular Biology, and \\ ${ }^{4}$ Department of Internal Medicine, University Hospital, University of Utrecht, The Netherlands
}

\begin{abstract}
Summary. Type 2 (non-insulin-dependent) diabetes is associated with the deposition of islet amyloid. The major formative peptide, islet amyloid polypeptide, has recently been characterised and an abnormality of the structure or expression of this gene is a possible candidate for the inherited component of Type 2 diabetes. A restriction fragment length polymorphism of the gene has been identified with Pvu II. To study the relationship between the islet amyloid polypeptide gene and Type 2 diabetes, two distinct genetic approaches have been undertaken. Firstly, non-linkage has been demonstrated in four pedigrees, with four normoglycaemic first degree relatives having an allele associated with diabetes in
\end{abstract}

other family members, and one affected relative not having the putatively associated allele. The LOD score taking agerelated penetrance into account was - 1.68, making linkage unlikely $(p=0.02)$. Secondly, in a population-based restriction fragment length polymorphism survey, no linkage disequilibrium of the alleles was found between a population of unrelated Caucasian subjects with Type 2 diabetes and a normal population. A mutation in or near the islet amyloid polypeptide gene is thus unlikely to be a common cause of Type 2 diabetes.

Key words: Linkage, islet amyloid.
A major genetic predisposition to Type 2 diabetes is shown by the near $100 \%$ concordance found in identical twins $[1,2]$. Whilst several genetic abnormalities probably contribute to the development of diabetes, a major single gene defect is suggested by the bimodality of glucose tolerance in three populations where the disease is common [3-5]. Similar bimodality has been shown in the first degree relatives of Caucasian Type 2 diabetic patients [6]. Köbberling and Tillil (1982) calculated that the ultimate prevalence of diabetes in the first degree relatives was $38 \%$ assuming that all relatives lived to age 80 years [7]. This is close to the $50 \%$ expected for an autosomal dominant disease. It is thought that other genetic and environmental factors contribute to the expression of the genetic abnormality [8] and some subjects may have a genetically determined increased risk of disease which is expressed at an early age, especially when associated with obesity [9].

The nature of the putative gene defect is unknown [10]. Insulin resistance is nearly always present in patients and contributes to the diabetes [11], but as it occurs in both glucose intolerant and normoglycaemic relatives, it may be an exacerbating rather than predisposing factor [12]. In Caucasian populations, impaired Beta-cell function appears to be the most characteristic abnormality of first degree relatives of subjects with Type 2 diabetes who have glucose intolerance [13, 14]. Progression from glucose intolerance to diabetes is accompanied by diminished Betacell function in a number of ethnic groups $[15,16]$. This has been interpreted to suggest that the major gene defect in Type 2 diabetes affects the Beta cells.

Deposition of amyloid is the most characteristic abnormality in the islets of Type 2 diabetic patients [17-19]. Amyloid deposition occurs in up to $90 \%$ of Caucasian Type 2 diabetic patients, and rarely in the normal population [20]. Amyloid deposition is also a prominent feature in diabetic Pima Indians, whereas it is rarely found in Pima Indians who were known to have normoglycaemia or impaired glucose tolerance [21]. The islet amyloid deposition occurs between the endocrine cells and the capillaries and it has been postulated that the deposition of islet amyloid may be a pathological factor interfering with the normal function of Beta cells [22], possibly eventually causing the moderate diminution of Beta cell numbers found in Type 2 diabetes [19].

The formative peptide of the islet amyloid of Type 2 diabetes is a 37 amino-acid polypeptide which has 43 and $46 \%$ homology with calcitonin gene-related peptide (CGRP) -I and -II, respectively [23, 24]. The islet amyloid polypeptide (IAPP) is a product of normal pancreatic Beta cells and is stored together with insulin in Beta cell 
granules [25]. The DNA sequence of the human gene encoding IAPP has been described [26,27]. It is a single copy gene located on chromosome 12 [26]. IAPP is synthesised as an 89 amino-acid residue prepropeptide which consists of a signal peptide followed by IAPP which is flanked by two short peptides [28]. The two flanking peptides are subsequently cleaved off at basic amino-acid residues. The availability of the c-DNA $[27,29]$ and the discovery of a restriction fragment length polymorphism (RFLP) [30] allows investigation of the association of the IAPP gene with Type 2 diabetes.

\section{Subjects and methods}

\section{Pedigreestudy}

The protocol was approved by the Central Oxford Research and Ethics Committee. Potentially informative families were obtained by examining DNA from 98 unrelated Type 2 diabetic patients to identify probands who were heterozygous for an IAPP marker. Twenty-one were heterozygous for the Pvu II RFLP for IAPP [30] with bands at $24 \mathrm{~kb}$ and $16 \mathrm{~kb}$. Blood samples for DNA analysis were obtained from their available first degree relatives. We describe the only four families in which a second member was diabetic or glucose intolerant and in whom sharing of a specific IAPP allele with the proband could be identified. The pedigrees are shown in Figure 1 and Table 1 gives details of the probands. The probands presented with Type 2 diabetes after 40 years of age. The clinical pattern of diabetes seen in these probands and their affected family members was indistinguishable from classic Type 2 diabetes. First degree relatives were screened with a $5 \mathrm{mg} \cdot \mathrm{kg}$ ideal body weight $\cdot \mathrm{min}^{-1} \mathrm{con}$ tinuous glucose infusion test [31]. Blood samples were obtained for glucose, insulin and C-peptide assay. Where glucose tolerance testing was not possible, fasting plasma glucose and insulin samples were obtained. Family members who were not available for investigation. were excluded from the study. As expected, several family members who were asymptomatic were found to have diabetes or glucose intolerance on testing.

The following subjects were considered affected: (1) Diabetes diagnosed by WHO criteria, and on therapy with oral hypoglycaemic agents, insulin or a specific diet. (2) Fasting hyperglycaemia,
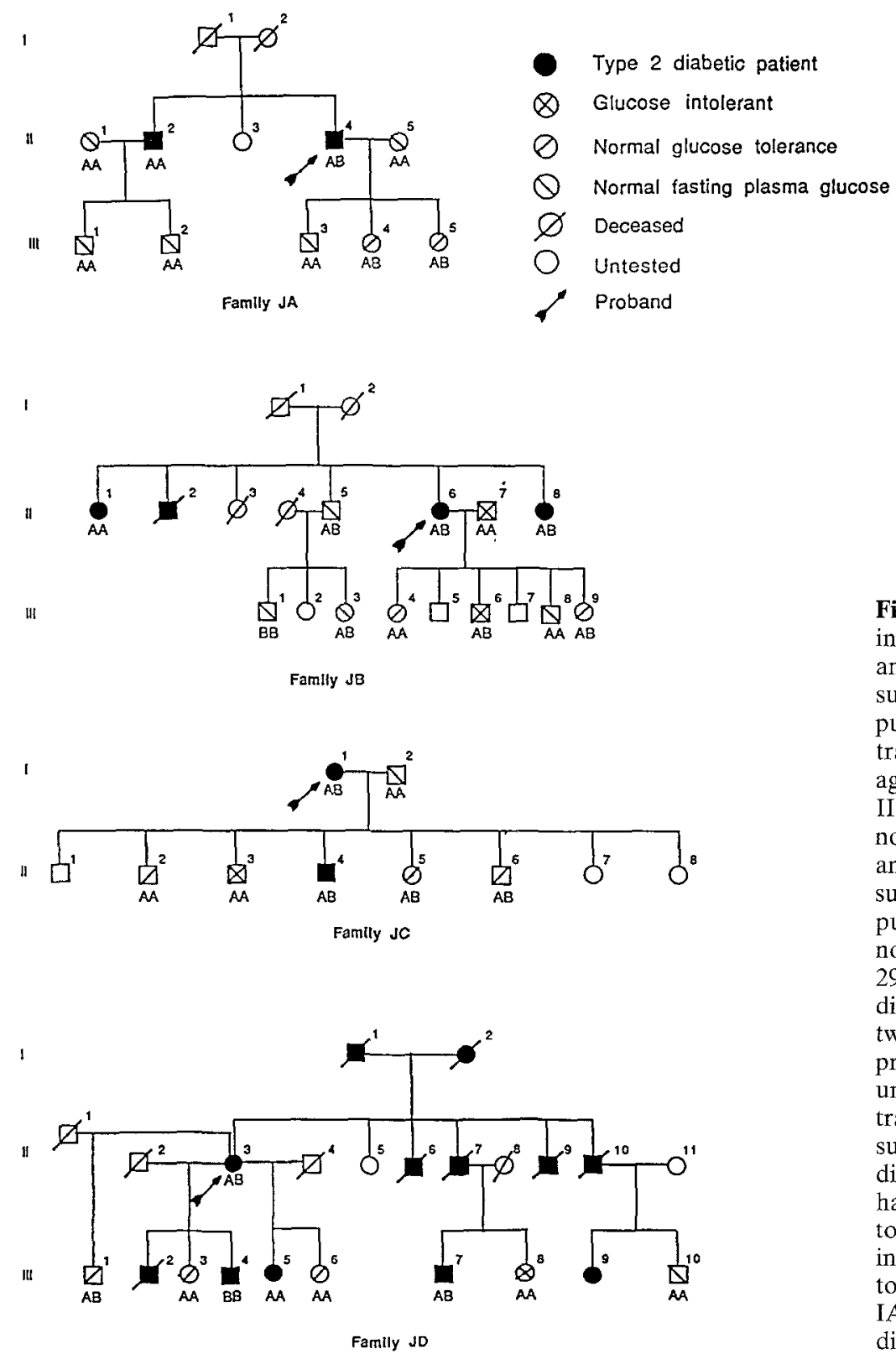

Fig. 1. Pedigrees of Type 2 diabetic families showing inheritance of islet amyloid polypeptide (IAPP) alleles and non-linkage with diabetes. Family JA. Type 2 diabetic subjects II 2 and II 4 share the " $A$ " allele which is the putative IAPP diabetic gene in this family, but subject II 4 transmits the "A" allele to normoglycaemic offspring III 3 aged 40 years. Family JB. Affected subjects II 1, II 6 and II 8 share the "A" allele, but subject II 6 transmits it to her normoglycaemic offspring III 4 and III 8 , aged 45 years and 40 years, respectively. Family JC. Type 2 diabetic subjects I 1 and II 4 share the " $B$ " allele, which is the putative IAPP diabetic gene in this family. However, normoglycaemic offspring II 5 and II 6 aged 31 years and 29 years received the "B" allele. The affected subject II 3 did not inherit the " $B$ " allele. Family JD. Subject II 3 had two affected parents and may have been homozygous for a predisposing gene for diabetes [9] and had three husbands unavailable for study. There was, however, no selective transmission of either the " $A$ " or " $B$ " allele to affected subjects III 4 and III 5 . Subject III 3 shares the putative diabetic IAPP genotype " $A$ " with her diabetic half-sister III 5 , but at age 45 has normal glucose tolerance. Key: Roman numerals on the left of the Figure indicate generation number. The " $A$ " and " $B$ " alleles refer to the $24 \mathrm{~kb}$ and $16 \mathrm{~kb}$ bands -respectively, detected with IAPP cDNA probe on Southern blots of genomic DNA digested with the restriction endonuclease Pvu II 
Table 1. Clinical details of diabetic probands

\begin{tabular}{|c|c|c|c|c|}
\hline Family & JA & JB & $\mathrm{JC}$ & JD \\
\hline Subject & II 4 & II 6 & I 1 & II 3 \\
\hline Sex & $\mathrm{M}$ & $\mathrm{F}$ & $\mathrm{F}$ & $\mathrm{F}$ \\
\hline $\begin{array}{l}\text { Age at diagnosis } \\
\text { (years) }\end{array}$ & 57 & 58 & 64 & 45 \\
\hline $\begin{array}{l}\text { Duration of } \\
\text { diabetes (years) }\end{array}$ & 3 & 8 & 3 & 23 \\
\hline $\begin{array}{l}\text { Height } \\
(\mathrm{cm})\end{array}$ & 167 & 163 & 158 & 158 \\
\hline $\begin{array}{l}\text { Weight } \\
(\mathrm{kg})\end{array}$ & 76 & 82 & 76 & 50 \\
\hline $\begin{array}{l}\text { Body mass index } \\
\left(\mathrm{kg} / \mathrm{m}^{2}\right)\end{array}$ & 27.3 & 30.9 & 30.4 & 20.0 \\
\hline Presentation & $\begin{array}{l}\text { thirst, } \\
\text { polyuria }\end{array}$ & $\begin{array}{l}\text { thirst, } \\
\text { nocturia, pru- } \\
\text { ritis vulvae }\end{array}$ & infection & $\begin{array}{l}\text { thirst, } \\
\text { pruritis } \\
\text { vulvae }\end{array}$ \\
\hline Initial therapy & diet & $\mathrm{OHA}$ & $\operatorname{diet}$ & diet \\
\hline $\begin{array}{l}\text { Time on initial } \\
\text { therapy (months) }\end{array}$ & 36 & 96 & 16 & 2 \\
\hline Current therapy & Diet & $\mathrm{OHA}$ & $\mathrm{OHA}$ & $\mathrm{OHA}$ \\
\hline Complications & nil & nil & nil & $\begin{array}{l}\text { CVA } \\
\text { retino- } \\
\text { pathy }\end{array}$ \\
\hline
\end{tabular}

Table 2. Age-related penetrance factors used in linkage analysis for the three putative genotypes (NN normal, ND heterozygote, DD homozygote) for Type 2 (non-insulin-dependent) diabetes

\begin{tabular}{lllll}
\hline Liability class & Age (years) & NN & ND & DD \\
\hline 1 & $>60$ & 0 & 0.8 & 0.95 \\
2 & $40-60$ & 0 & 0.45 & 0.9 \\
3 & $<40$ & 0 & 0.25 & 0.8 \\
\hline
\end{tabular}

with a fasting plasma glucose concentration $>6 \mathrm{mmol} / \mathrm{h}$, which is $>3$ standard deviations above the mean of a normal population. (3) Glucose intolerance, defined as plasma glucose levels $>2$ standard deviations above the mean of an age and body-weight matched normal population, one hour after a continuous infusion of glucose $5 \mathrm{mg} \cdot \mathrm{kg}$ ideal body weight $\cdot \mathrm{min}^{-1}$. In the families studied only one member was classified as abnormal on this basis alone, the others also having fasting hyperglycaemia.

\section{Population study}

Eighty-eight unrelated Type 2 diabetic subjects were Caucasians from the Oxford UK Prospective Diabetes Study clinic [32]. Sixtyseven non-diabetic subjects included 15 normoglycaemic Caucasians aged 59-94 years, and 52 Oxford blood donors.

\section{DNA studies}

DNA was extracted from blood samples using standard methods. $5 \mu \mathrm{g}$ of DNA was digested with a three-fold excess of the restriction endonuclease Pvu II (Anglian Biotech, Colchester, UK) in accordance with the manufacturer's instructions. The resulting fragments were electrophoresed in $0.8 \%$ agarose gels, denatured, neutralized and transferred using Southern blotting on to nylon filters (Hybond$\mathrm{N}$ Amersham, UK). The filters were subsequently hybridized with a ${ }^{32} \mathrm{P}$-labelled islet amyloid polypeptide c-DNA probe (Sc IAP-8) by hexanucleotide labeiling, using a commercial kit (Pharmacia, Milton Keynes, UK). Sc IAP-8 contains the 588 bp EcoR1 insert encoding $\lambda$ hIAPP-C1 [28]. Following hybridization the filters were washed and subjected to autoradiography. Pvu II digestion of genomic DNA identified a two allele polymorphism with bands at $24 \mathrm{~kb}$ (allele A) and $16 \mathrm{~kb}$ (allele B). The location of the Pvu II restriction site within the IAPP gene is unknown.

\section{Linkage analysis}

Linkage analysis was performed with version 4.8 of the LINKAGE computer programes. The putative gene frequency used for Type 2 diabetes was 0.10 , based on prevalence studies in a Caucasian population [33]. As the probe for a candidate gene was being examined, LOD score was calculated with the recombination fraction theta equal to zero. The age-dependent penetrance factors (Table 2) were derived from the studies of Köbberling and Tillil [7], O'Rahilly et al. [9] and Page et al. [35]. For example, the $5 \mathrm{mg} \cdot \mathrm{kg}$ ideal body weight $\cdot \mathrm{min}^{-1}$ glucose infusion test in first degree relatives, aged 40-49 years, of Type 2 diabetic patients found $22 \%$ to have impaired glucose tolerance. On a dominant gene hypothesis this would represent $44 \%$ of those potentially affected [35].

\section{Results}

\section{Pedigree data}

The pedigrees and IAPP haplotypes for the four families are shown in Figure 1. Inspection of the pedigrees excludes close linkage between identified alleles of the IAPP gene and Type 2 diabetes. In each of the four families, a first degree relative with diabetes or glucose intolerance could be identified as having one of the two alleles of the proband, and this was assumed to be the putative IAPP gene associated with diabetes. In each family, normoglycaemic first degree relatives could be identified with the same allele, four of these subjects being aged more than 40 years (Table 3 ). Age-dependent penetrance factors allowed for uncertainty in the diagnosis of normality in these individuals. In the family JC, one affected family member did not share the same allele as two other affected family members. The formal LOD score (logarithm of the odds for linkage between the IAPP locus and Type 2 diabetes) of -1.68 made it unlikely $(p=0.02)$ that a defect in the IAPP gene is the cause of diabetes in these families.

\section{Population data}

No significant difference in the frequency of the polymorphisms at $24 \mathrm{~kb}(\mathrm{~A})$ and $16 \mathrm{~kb}$ (B) was demonstrated between the 88 unrelated Caucasian subjects with Type 2 diabetes, 15 Caucasian non-diabetic control subjects and 52 randomly-selected blood donors (Table 4). 
Table 3. Normoglycaemic subjects with allele for islet amyloid polypeptide associated with diabetes in two or more members of the pedigree

\begin{tabular}{lllll}
\hline Family & JA & JB & JC & JD \\
\hline Subject & III 2 & III 8 & II 4 & III 3 \\
Age (years) & 40 & 40 & 45 & 43 \\
Gender & male & male & female & female \\
BMI $\left(\mathrm{kg} / \mathrm{m}^{2}\right)$ & 26.5 & 26.9 & 40.0 & 23.5 \\
$\mathrm{HbA}_{1 \mathrm{c}}(\%)$ & 5.4 & 4.6 & 4.8 & 5.6 \\
FPG $(\mathrm{mmol} / \mathrm{l})$ & 4.5 & 4.4 & 5.2 & 4.3 \\
APG $(\mathrm{mmol} / \mathrm{l})$ & - & - & 7.7 & 8.4 \\
Z(SD) & - & - & 0.7 & 0.1 \\
FPI $(\mathrm{pmol} / \mathrm{l})$ & - & - & 55.3 & 33.7 \\
API $(\mathrm{pmol} / \mathrm{l})$ & - & - & 191.7 & 89.0
\end{tabular}

Abbreviations: BMI - body mass index; $\mathrm{HbA}_{\mathrm{lc}}-$ glycosylated haemoglobin (normal range \pm 2 SD 4.3-6.1); FPG - fasting plasma glucose; $\mathrm{APG}$ - achieved plasma glucose at $60 \mathrm{~min}$ of glucose infusion; Z-standardized residual from the prediction of an age and \% ideal body weight regression model applied to a population of 105 normal subjects; FPI - fasting plasma insulin; API - achieved plasma insulin at $60 \mathrm{~min}$ of glucose infusion

Table 4. Islet amyloid polypeptide (IAPP) genotypes of diabetic and non-diabetic populations. Polymorphism for IAPP was demonstrated by a band at $24 \mathrm{~kb}$ (allele "A") and $16 \mathrm{~kb}$ (allele "B")

\begin{tabular}{lllrl}
\hline & (n) & AA & AB & BB \\
\hline Type 2 diabetic subjects & 88 & 74 & 14 & 0 \\
Normoglycaemic control subjects & 15 & 12 & 3 & 0 \\
Blood donors & 52 & 40 & 11 & 1
\end{tabular}

The frequency of alleles " $A$ " and " $B$ " in each group was tested by $\mathrm{X}^{2}=2.72$ with 4 degrees of freedom (not significant)

\section{Discussion}

The demonstration of non-linkage of the IAPP gene with Type 2 diabetes in four Caucasian families together with the lack of linkage disequilibrium in the population study make it unlikely that a defect in or near the IAPP gene is a common cause of Type 2 diabetes. Linkage analysis in pedigrees is a powerful tool for examining the role of candidate genes in the aetiology of inherited diseases with a defined mode of transmission [37]. The linkage analysis assumes that Type 2 diabetes has a major single-gene autosomal dominant genetic component as suggested by bimodality in population studies [3-6]. The late age of onset and the frequency of subclinical disease have made it difficult to define the mode of inheritance. However, the suggestion that the common form of Type 2 diabetes results from an autosomal dominant trait with a penetrance dependent upon age and obesity is supported by results from family studies in which ultimate prevalence was estimated by statistical extrapolation [7] and in the prevalence of abnormality in first degree relatives of Type 2 diabetic patients [9]. This view is supported by a recent WHO expert committee [38].

When performing linkage analysis in Type 2 diabetes the complicating factors of high disease prevalence and late age of onset must be considered. Age-dependent penetrance allows for uncertainty in the exclusion of identification of diabetes and reduces the risk of spuriously elevated LOD scores, whether positive or negative. The penetrance factors used in this study were calculated from the studies of first degree relatives of Type 2 diabetic subjects assuming dominant inheritance $[7,9,35]$ and from studies of asymptomatic women who have had gestational diabetes and were studied by glucose tolerance tests [39]. The gene frequency for the disease in the normal population is assumed from the $10 \%$ prevalence of known diabetes in a Caucasian population in the 8th decade [33].

The biological rationale for population-based RFLP surveys relies on the concept of non-random association of alleles with putative disease susceptibility genes giving linkage disequilibrium [40]. If a mutated IAPP gene existed in Type 2 diabetic patients, it would probably be in linkage with DNA polymorphisms within or flanking the gene, as demonstrated with sickle cell anaemia and the thalassaemias [41]. The population study data demonstrated no significant difference in the frequency of the IAPP alleles between Caucasian Type 2 diabetic subjects, Caucasian non-diabetic control subjects and randomlyselected blood donors. The lack of linkage disequilibrium demonstrated in the population study provides no suggestive evidence for the presence of a mutated IAPP gene in Type 2 diabetic patients.

The deduced amino-acid sequence of the IAPP encoding gene [26] reveals that the normally occurring polypeptide is identical to the polypeptide isolated from pancreatic amyloid $[23,24]$. This provides further evidence to suggest that amyloidogenesis is not due to the presence of a mutated form of IAPP. Similarly there is no identified gene defect of the formative amyloid peptide found in Alzheimer's disease [42]. This is in contrast to the molecular basis of amyloid deposition in familial amyloidotic polyneuropathy [43] and hereditary cerebral haemorrhage with amyloidosis [44] where the synthesis of a genetically abnormal protein is thought to facilitate the deposition of amyloid.

The mechanisms leading to islet amyloid formation in Type 2 diabetes are unknown: amyloidogenesis may result from altered levels of expression of the IAPP gene, overproduction or decreased catabolism of the peptide. Abnormal clearance of the IAPP precursor molecule may be an aetiological factor, analogous to the putative role of defective proinsulin processing in Type 2 diabetes [45]. In addition to the mature IAPP, the N-terminal flanking peptide has been identified in islet amyloid deposits [46].

The demonstration of non-linkage of the IAPP gene with Type 2 diabetes in four Caucasian families together with the lack of linkage disequilibrium in the population study make it unlikely that a mutation of the IAPP gene is associated with Type 2 diabetes. This does not exclude the excessive deposition of islet amyloid from being a major factor in the development of Type 2 diabetes.

Acknowledgements. We are grateful to the families for their collaboration, to Dr. W. Cookson for assistance with LOD score analyses, to Mrs. B. Barrow and Mrs. N. Walravens for their help with glucose tolerance tests, to Mrs. M.Burnett, Mrs. P. Sutton and Mr. D.Jelfs for their technical assistance. This study is supported by a grant from the Medical Research Council. Dr. J. Cook is a Rhodes scholar. 


\section{References}

1. Barnett AH, Eff C, Leslie RDG, Pyke DA (1981) Diabetes in identical twins: a study of 200 pairs. Diabetologia 20: 87-93

2. Barnett AH, Spiliopoulos AJ, Pyke DA, Stubbs WA, Burrin J, Alberti KGMM (1981) Metabolic studies in unaffected co-twins of non-insulin dependent diabetics. Br J Med 282: $1656-1658$

3. Rushforth NB, Bennett PH, Steinberg AG, Burch TA, Miller M (1971) Diabetes in the Pima Indians; evidence of bimodality in glucose tolerance distributions. Diabetes 20: 756-765

4. Zimmet P, Whitehouse S (1978) Bimodality of fasting and two hour glucose tolerance distributions in a Micronesian population. Diabetes 27: 793-800

5. Raper LR, Taylor R, Zimmet P, Milne B, Balkan B (1984) Bimodality in glucose tolerance distributions in the urban Polynesian population of Western Samoa. Diabetes Res 1: 1926

6. Tillil H, Richter K, Kobberling J (1985) Bimodal distribution of the 2-hour blood glucose value during OGTT among first-degree relatives of Type 2 diabetics in a Caucasoid population. Diabetes Res Clin Pract, Suppl 1 (Abstract)

7. Köbberling J, Tillil H (1982) Empirical risk figures for the first degree relatives of non-insulin dependent diabetics. In: Köbberling J, Tatersall R (eds) The genetics of diabetes mellitus. Academic Press, London, pp 201-209

8. Beaty T, Neel J, Fajans S (1982) Identifying risk factors for diabetes in first-degree relatives of non-insulin dependent diabetic patients. Am J Epidemiol 115:380-397

9. O'Rahilly S, Spivey RS, Holman RR, Nugent Z, Clark A, Turner RC (1987) Type 2 diabetes of early onset: a distinct clinical and genetic syndrome? Br J Med 294: 923-928

10. O'Rahilly S, Wainscoat JS, Turner RC (1988) Type 2 (non-insulin-dependent) diabetes. New genetics for old nightmares. Diabetologia 31: 407-414

11. Kahn CR (1986) Insulin resistance: a common feature of diabetes mellitus. N Engl J Med 315:252-254

12. Erikson J, Fransail-Kallunki A, Ekstrand A, Saloranta C, Widén E, Schalin C, Groop L (1989) Early metabolic defects in persons at increased risk for non-insulin-dependent diabetes mellitus. $\mathrm{N}$ Engl J Med 321: 337-343

13. O'Rahilly S, Nugent Z, Rudenski A, Hosker JP, Burnett MA, Darling P, Turner RC (1986) Beta-cell dysfunction rather than insulin insensitivity is the primary defect in familial Type 2 diabetes. Lancet II: 360-364

14. O'Rahilly S, Turner RC, Matthews DR (1988) Impaired pulsatile secretation of insulin in relatives of patients with non-insulin-dependent diabetes. N Engl J Med 318: 1225-1230

15. Kadowaki T, Miyake Y, Hagura R, Akanuma Y, Kajinuma H, Kuzuya N, Takaku F, Kosaka K (1984) Risk factors for worsening to diabetes in subjects with impaired glucose tolerance. Diabetologia 26: 44-49

16. Lillioja S, Mott DM, Howard BV, Bennett PH, Yki-Järvinen H, Freymond D, Nyomba BL, Zurlo F, Swinburn B, Bogardus C (1988) Impaired glucose tolerance as a disorder of insulin actionlongitudinal and cross-section studies in Pima Indians. N Engl J Med 318: 1217-1225

17. Schneider HM, Storkel S, Will W (1980) Das amyloid der Langerhanssch Inseh und Seine Beziehung zum Diabetes mellitus. Dtsch Med Wochenschr 105: 1143-1147

18. Maloy AL, Longnecker DS, Greenberg ER (1981) The relation of islet amyloid to the clinical type of diabetes. Hum Pathol 12: 917-922

19. Clark A, Wells CA, Buley ID, Cruickshank JM, Vanhegan RI, Matthews DR, Cooper GJS, Holman RR, Turner RC (1988) Islet amyloid, increased A-cells, reduced Beta-cells and exocrine fibrosis: quantitative changes in the pancreas in Type 2 diabetes. Diabetes Res 9: 151-159

20. Clark A (1989) Islet amyloid and Type 2 diabetes. Diab Med 6: $561-567$
21. Clark A, Saad MF, Nezzer T, Uren C, Knowier WC, Bennett PH, Turner RC (1990) Islet amyloid in diabetic and non-diabetic Pima Indians. Diabetologia 33: 285-289

22. Clark A, Cooper GIS, Lewis CE, Morris JF, Willis AC, Reid KBM, Turner RC (1987) Islet amyloid formed from diabetes-associated peptide may be pathogenic in Type 2 diabetes. Lancet II: $231-234$

23. Cooper GJS, Willis AC, Clark A, Turner RC, Sim RB, Reid KBM (1987) Purification and characterization of a peptide from amyloid-rich pancreases of Type 2 diabetic patients. Proc Nat Acad Sci 84: 8628-8632

24. Westermark P, Wernstedt C, O'Brien TD, Hayden DW, Johnson $\mathrm{KH}$ (1987) Islet amyloid in Type 2 human diabetes mellitus and adult diabetic cats contains a novel putative polypeptide hormone. Am J Pathol 127: 414-417

25. Lukinius A, Wilander E, Westermark GT, Engström U, Westermark P (1989) Co-localization of islet amyloid polypeptide and insulin in the Beta-cell secretory granules of the human pancreatic islets. Diabetologia 32: 240-244

26. Mosselman S, Höppener JWM, Zandberg J, Van Mansfeld ADM, Guerts Van kessel AHM, Lips CJM, Jansz HS (1988) Islet amyloid polypeptide: identification and chromosomal localization of the human gene. FEBS Lett 239: 227-232

27. Mosselman S, Höppener JWM, Lips CJM, Jansz HS (1989) The complete islet amyloid polypeptide precursor is encoded by two exons. FEBS Lett 247: 154-158

28. Sanke T, Bell GI, Sample C, Rubenstein AH, Steiner DF (1988) An islet amyloid peptide is derived from an 89-amino-acid precursor by proteolytic processing. J Biol Chem 263: 17243-17246

29. Betsholtz C, Svensson V, Rorsman F, Engström U, Westermark GT, Wilander E, Johnson K, Westermark P (1989) Islet amyloid polypeptide (IAPP). cDNA cloning and identification of an Amyloidogenic Region Associated with the species-specific occurrence of age-related diabetes mellitus. Exp Cell Res 183: 484493

30. Patel P, Mosselman S, Höppener JWM, Jansz HS, Clark A, O'Rahilly S, Turner RC, Wainscoat JS (1989) An RFLP associated with insulinoma amyloid polypeptide locus (IAPP). Nucl Acids Res 17: 6758

31. Hosker JP, Matthews DR, Rudenski AS, Burnett MA, Darling P, Bown EG, Turner RC (1985) Continuous infusion of glucose with model assessment: measurement of insulin resistance and Beta-cell function in man. Diabetologia 28: 401-411

32. Multicentre Study (1983) UK prospective study of therapies of maturity-onset diabetes. Diabetologia 24: 404-411

33. Harris M, Hadden W, Knowler WC, Bennett CH (1987) Prevalence of diabetes and impaired glucose tolerance and plasma glucose levels in US population aged 20-74 yr. Diabetes 36 : 523 534

34. O'Rahilly SP, Trembath RC, Patel P, Galton DJ, Turner RC, Wainscoat JS (1988) Linkage analysis of the human insulin receptor gene in Type 2 (non-insulin-dependent) diabetic families and a family with maturity onset diabetes of the young. Diabetologia 31: 792-797

35. Page RCL, Walravens EKN, Manley SE, Turner RC (1989) Screening for diabetes and glucose intolerance in children of elderly Type 2 diabetic subjects). Diab Med 6[Suppl 1]: A38 (Abstract)

36. Westermark P, Wernstedt C, Wilander E, Hayden DW, O'Brien TD, Johnson KH (1987) Amyloid fibrils in human insulinoma and islets of Langerhans of the diabetic cat are derived from a neuropeptide-like protein also present in normal islet cells. Proc Natl Acad Sci USA 84: 3881-3885

37. Ott J (1985) Analysis of human genetic linkage, 1st edn. John Hopkins University Press, Baltimore

38. WHO technical report series (1985) no 727, Geneva

39. Page RCL, Walravens EKN, Levy JC, Turner RC (1989) Screening subjects at increased risk of developing Type 2 diabetes. Diab Med 6 [Suppl 2]: P50 (Abstract)

40. Cox NJ, Bell G (1989) Disease associations: chance, artefact or susceptibility genes. Diabetes 38: 947-950 
41. Orkin SH, Kazazian HH Jr (1984) The mutation and polymorphism of the human beta-globin gene and its surrounding DNA. Ann Rev Genet 18: 131-171

42. Van Broeckhoven C, Genthe AM, Vandenberghe A, Horsthemke B, Backhovens H, Raeymaekers P, Van Hul W, Wehnert A, Ghevens J, Cras P, Bruyland M, Martin JJ, Salbaum M, Mutthaup G, Masters CL, Beyreuther K, Gurling HMD, Mullan MJ, Holland A, Barton A, Irving N, Williamson R, Richards SJ, Hardy JA (1987) Failure of familial Alzheimer's disease to segregate with the A4-amyloid gene in several European families. Nature 329: 153-155

43. Yoshioka K, Sasaki H, Yoshioka N, Furuya H, Harada T, Kito S, Sakaki Y (1986) Structure of the mutant prealbumin gene responsible for familial amyloidotic polyneuropathy. Mol Biol Med 3: 319-328

44. Ghiso J, Jensson O, Fragione B (1986) Amyloid fibrils in hereditary cerebral haemorrhage with amyloidosis of Icelandic type is a variant of gamma-trace basic protein (cystatin C). Proc Natl Acad Sci USA 83: 2974-2978
45. Porte D Jr, Khan S (1989) Hyperproinsulinemia and amyloid in NIDDM - clues to the etiology of islet Beta-cell dysfunction? Diabetes 38: 1333-1336

46. Westermark P, Engström U, Westermark G, Johnson K, Permerth J, Betsholtz C (1989) Islet amyloid polypeptide (IAPP) and pro-IAPP immunoreactivity in human islets of Langerhans. Diab Res Clin Pract 7:219-226

Received: 19 April 1990

and in revised form: 10 July 1990

Dr. J. Cook

Diabetes Research Laboratories

Radcliffe Infirmary

Woodstock Road

Oxford OX2 6HE

UK 